\title{
Correction to: Effect of Golimumab Dose Escalation in Japanese Patients With Rheumatoid Arthritis: Post- Hoc Analysis of Post-Marketing Surveillance Data
}

\author{
Hirohito Shimizu • Hisanori Kobayashi · Masayoshi Kanbori • \\ Yutaka Ishii
}

Published online: October 8, 2020

(C) The Author(s) 2020

Correction to: Rheumatol Ther (2020) 7:311-325 https://doi.org/10.1007/s40744020-00198-4

Under Results section, heading: Effectiveness of GLM Stratified by the Time to Dose Escalation, the remission based on values of DAS28, SDAI, and CDAI was published incorrectly. The correct values are: $16.1 \%, 5.0 \%$ and $4.3 \%$.

The original article can be found online at https://doi org/10.1007/s40744-020-00198-4.

H. Shimizu $(\varangle) \cdot$ Y. Ishii

Medical Affairs Division, Immunology Department, Janssen Pharmaceutical K.K, Tokyo, Japan

e-mail: hshimi10@its.jnj.com

H. Kobayashi

Clinical Science Division, External Collaboration and Portfolio Management Department, R\&D Janssen Pharmaceutical K.K., Tokyo, Japan

M. Kanbori

Japan Safety \& Surveillance Division, Research \& Development Division, Janssen Pharmaceutical

K.K., Tokyo, Japan
And also, the title of the Table 2 is incorrect. The correct title is Univariate and multivariate logistic regression analyses of patient variables associated with likelihood of achieving a good or moderate EULAR response after 24 weeks of GLM treatment.

\section{OPEN ACCESS}

This article is licensed under a Creative Commons Attribution-NonCommercial 4.0 International License, which permits any noncommercial use, sharing, adaptation, distribution and reproduction in any medium or format, as long as you give appropriate credit to the original author(s) and the source, provide a link to the Creative Commons licence, and indicate if changes were made. The images or other third party material in this article are included in the article's Creative Commons licence, unless indicated otherwise in a credit line to the material. If material is not included in the article's Creative Commons licence and your intended use is not permitted by statutory regulation or exceeds the permitted use, you will need to obtain permission directly from the copyright holder. To view a copy of this licence, visit http://creativecommons.org/licenses/by$\mathrm{nc} / 4.0 /$. 